\title{
Effect of toxicity in Folsomia candida by the use of fungicide and insecticide in subtropical soil
}

\author{
Efeito da toxicidade em Folsomia candida pelo uso de fungicida e insecticida em solos subtropicais
}

Isabela Aparecida Giordani ${ }^{1}\left(\mathbb{1}\right.$, Eduarda Busatta $^{2}\left(\mathbb{C}^{\circ}\right.$, Elizeu Bonfim ${ }^{2}\left({ }^{\circ}\right.$, Luís Carlos Iuñes Oliveira Filho ${ }^{3}$, Dilmar Baretta ${ }^{4}$, Carolina Riviera Duarte Maluche Baretta ${ }^{5}$ (0)

\section{A B S T R A C T}

Pesticides are widely used for control and prevention against agricultural pests and diseases. The use of these products can negatively affect non-target organisms with important role in soil such as springtails. The present study aimed to evaluate the toxicity of two commercial formulations of pesticides on soil fauna using the springtail Folsomia candida. A natural soil classified as Inceptisol, characteristic of the western region of the Santa Catarina State, was used. The treatments in both tests consisted of six concentrations of the fungicide Comet $^{\circledR}$ (a.i. pyraclostrobin) $\left(0.35 ; 0.70 ; 1.40 ; 2.10 ; 2.80\right.$ and $4.00 \mathrm{mg} \mathrm{kg}^{-1}$ of soil) and of the fungicide + insecticide Standak ${ }^{\circledR} \mathrm{Top}$ (a.i. pyraclostrobin + thiophanate-methyl + fipronil) $(0.20 ; 0.60 ; 1.20 ; 1.80 ; 2.40$ and 3.00 $\mathrm{mg} \mathrm{kg}^{-1}$ soil), plus the control treatment. Acute and chronic tests were carried out following ISO guidelines. Both products proved to be toxic to the evaluated species. Lethality effects were observed in relation to the control of the organisms exposed to low concentrations of the fungicide (0.35 mg kg-1 soil); while for the fungicide + insecticide formulation, lethality was observed at higher concentrations, from $2.40 \mathrm{mg} \mathrm{kg}^{-1}$ soil (LC50 > $3.00 \mathrm{mg} \mathrm{kg}^{-1}$ soil). The reproductive rate was affected only in organisms exposed to the fungicide, with a reduction in the number of juveniles at concentration from $4.00 \mathrm{mg} \mathrm{kg}^{-1}$ soil, with $\mathrm{EC}_{20}$ of $3.38 \mathrm{mg}$ $\mathrm{kg}^{-1}$ soil (2.79-3.96). The results indicate that springtails are sensitive to the tested products, especially to the fungicide that contains the highest concentration of pyraclostrobin in the composition.

Keywords: springtails; pesticides; Inceptisol; edaphic fauna; terrestrial ecotoxicology.

\section{RE S U M 0}

Os agrotóxicos são amplamente utilizados para o controle e a prevenção de pragas e doenças agrícolas. O uso desses produtos é capaz de afetar de maneira negativa organismos não alvos de papel significante no solo, como os colêmbolos. O presente estudo teve como objetivo avaliar a toxicidade de duas formulações comerciais na fauna do solo utilizando o colêmbolo Folsomia candida. Foi utilizado um solo natural classificado como Cambissolo Húmico, característico da região oeste do Estado de Santa Catarina. Os tratamentos nos dois testes consistiram em seis concentrações do fungicida Comet $^{\circledast}$ (i.a. piraclostrobina) $\left(0,35 ; 0,70 ; 1,40 ; 2,10 ; 2,80\right.$ e $4,00 \mathrm{mg} \mathrm{kg}^{-1}$ de solo) e do fungicida + inseticida Standak ${ }^{\circledast} \mathrm{Top}$ (p.a. piraclostrobina + tiofanato metílico + fipronil) $\left(0,20 ; 0,60 ; 1,20 ; 1,80 ; 2,40\right.$ e $3,00 \mathrm{mg} \mathrm{kg}^{-1}$ de solo), acrescidos do tratamento controle. Testes agudos e crônicos foram realizados de acordo com protocolos ISO. Ambos os produtos demonstraram ser tóxicos para a espécie avaliada. Efeitos de letalidade foram observados em relação ao controle dos organismos expostos em baixas concentrações do fungicida (0,35 mg kg-1 solo), enquanto para a formulação do fungicida + inseticida a letalidade foi observada em concentrações mais altas, a partir de $2,40 \mathrm{mg} \mathrm{kg}^{-1}$ solo (CL50 > 3,00 mg kg-1 solo). A taxa de reprodução foi afetada somente nos organismos expostos ao fungicida, com redução no número de juvenis em concentração a partir de 4,00 $\mathrm{mg} \mathrm{kg}^{-1}$ solo, com $\mathrm{CE}_{20}$ estimado de 3,38 $\mathrm{mg} \mathrm{kg}^{-1}$ solo $(2,79-3,96)$. Os resultados obtidos indicam que os colêmbolos apresentam sensibilidade aos produtos testados, especialmente ao fungicida que contém maior concentração de piraclostrobina em sua composição.

Palavras-chave: colêmbolos; pesticidas; Cambissolo Húmico; fauna edáfica; ecotoxicologia terrestre.

\footnotetext{
${ }^{1}$ Master's degree in Environmental Sciences, Universidade Comunitária da Região de Chapecó (Unochapecó) - Chapecó (SC), Brazil.

${ }^{2}$ Student of Biological Sciences graduation, Unochapecó - Chapecó (SC), Brazil.

${ }^{3}$ Postdoctoral student, Universidade do Estado de Santa Catarina (UDESC) - Chapecó (SC), Professor, Universidade Federal de Pelotas - Capão do Leão (RS), Brazil.

${ }^{4}$ Professor, UDESC - Chapecó (SC), Brazil.

${ }^{5}$ Professor, Unochapecó - Chapecó (SC), Brazil.

Correspondence address: Carolina Riviera Duarte Maluche Baretta - Universidade Comunitária da Região de Chapecó - Rua Servidão Anjo da Guarda, 295-D - Bairro Efapi - CEP: 89809-900 - Chapecó (SC), Brazil - E-mail: carolmaluche@unochapeco.edu.br

Conflicts of interest: the authors declare that there are no conflicts of interest.

Funding: Universidade Comunitária da Região de Chapecó (Unochapecó) and Coordenação de Aperfeiçoamento de Pessoal de Nível Superior (Capes).
}

Received on: 02/04/2020. Accepted on: 05/29/2020.

https://doi.org/10.5327/Z2176-947820200692 


\section{Introduction}

Pesticides are widely used in the agricultural sector for the control or prevention against the onset of pests and diseases, and the expansion of agricultural frontiers has increased their use (MAJOLO; REMPEL, 2018; NASCIMENTO; NAVAL, 2019; LORENZATTO et al., 2020). Their continuous and frequent use has allowed Brazil to become the largest consumer of agrochemicals since 2008, consuming about $20 \%$ of the total marketed in the world (CARNEIRO et al., 2015; PELAEZ et al., 2015). According to data from the institute that protects and monitors the environment and renewable resources (IBAMA, 2019), it is estimated that, in the year 2017, consumption in Brazil reached 540,000 tons of active ingredients (a.i.). Among the categories of pesticides most sold in the national market, fungicides (13.4\%) and insecticides (10.4\%) are widely used (IBAMA, 2019). The climate change observed in recent years, as well as an agriculture often based on a low diversity of species, are directly related to an environment that makes crops a favorable scenario for fungal diseases and pest attack (YOUNG et al., 2019). This fact causes a large consumption of fungicide and insecticide products in a preventive way or for the control of the pest itself. The toxicity of pesticides can pose a risk to non-target organisms of soil fauna.

In agricultural crops, a wide variety of commercial formulations are used, among them Comet ${ }^{\circledR}$ (a.i. pyraclostrobin) and Standak ${ }^{\circledR}$ Top (a.i. fipronil + pyraclostrobin + thiophanate-methyl). Pyraclostrobin is a strobilurin fungicide, recommended for agricultural and forestry crops (BRASIL, 2020). Thiophanate-methyl is a benzimidazole fungicide with indication for agricultural crops (BRASIL, 2020). Fipronil is a pyrazole insecticide, recommended for agricultural crops (BRASIL, 2020). These substances are commonly marketed with formulations composed of a single active ingredient, or through multiple mixtures of active ingredient, although there is little knowledge about the possible synergistic and antagonistic effects between these multiple mixtures found in commercial and field-applied products (YANG et al., 2017). The toxicity effect depends on each mixture, even if the molecules present in the formulations have the same mode of action (KOUTSAFTIS; AOYAMA, 2007; YANG et al., 2017). However, it is recommended that tests be carried out on the combined effects of pesticides that are found in the environment (EC, 2012). Some adverse effects on non-target organisms have been reported, such as negative influence of fipronil (ZORTÉA et al., 2018a; 2018b) and pyraclostrobin (MA et al., 2019; ZHANG et al., 2019) in pesticide formulations with only one active ingredient. However, no other studies were found testing the hazard of these commercial formulations evaluated in the present study for soil organisms, such as Folsomia candida.

Due to the frequent and repeated use of pesticides applied in agricultural areas, such products may directly or indirectly affect edaphic fauna. Although the application of agrochemicals is often not carried out directly in the soil, pesticides are sprayed on the plants and part of the spray reaches the soil (BERTRAND et al., 2015). It has been esti- mated that $99.9 \%$ of pesticides used move into the environment (PIMENTEL, 1995) where they adversely affect soil organisms. The use of these products is capable of causing irreversible damage to the soil ecosystem (DABROWSKI; SHADUNG; WEPENER, 2014), mainly through the use of substances that may indirectly affect the important role played by organisms in this environment.

Although they represent a small proportion of the soil biomass, springtails participate in the process of organic matter decomposition and nutrient cycling, and stimulate the activity of bacterial and fungal colonies, being fundamental for soil fertility (BUCH et al., 2016). The $F$. candida species is recommended for ecotoxicological tests (ISO, 1999). These organisms are considered bioindicators because of their sensitivity to contaminants, as well as the ease of sampling and cultivating them under laboratory conditions. Recent studies show the sensitivity of these organisms to the application of fungicides and insecticides, which affect the survival, reproduction and gene expression, also causing effects of genotoxicity and cytotoxicity on the species (JEGEDE; OWOJORI; RÖMBKE, 2017; GÜNDEL et al., 2019; SIMÕES et al., 2019).

The present study aimed to evaluate the ecotoxicity of different concentrations of two commercial formulations of fungicide (a.i. pyraclostrobin) and fungicide + insecticide (a.i. pyraclostrobin + thiophanate-methyl + fipronil), on the survival and reproduction of $F$. candida through standardized tests in subtropical natural soil.

\section{Material and Methods}

\section{Test organisms}

The tests were performed with springtails of the species $F$. candida, with age synchronized between 10 and 12 days, cultivated in plastic pots containing a mixture of gypsum and activated charcoal in the proportion of 11:1 and deionized water, fed weekly with yeast (Saccharomyces cerevisiae), according to the recommendations of the reference protocol ISO 11267 (ISO, 1999), obtained from the establishment in the Soil Laboratory of Universidade Comunitária da Região de Chapecó (Unochapecó). The cultures of organisms and tests were conducted in a controlled environment with a temperature of $20 \pm 2^{\circ} \mathrm{C}$, with photoperiod of 12:12 h (light:dark).

\section{Soil test}

The soil used for the tests was the Inceptisol, chosen for its ecological relevance and presented as a highly representative soil class in Brazil and in the State of Santa Catarina. The soil was collected at 0-10 $\mathrm{cm}$ depth in the city of Guatambú, Santa Catarina [27\%05'574" S and $52^{\circ} 49^{\prime} 177^{\prime \prime}$ W], with no history of agricultural use, sifted and dried. Soil $\mathrm{pH}$ was adjusted to $6.0 \pm 0.5$ with addition of $\mathrm{CaCO}_{3}$ and its moisture was corrected at the beginning of the test to $60 \%$ of the maximum water retention capacity (WRC). The physical-chemical parameters of the natural soil were determined according to the methodology de- 
scribed by Tedesco et al. (1995) and Embrapa (2011). The soil characterization was: clay $26.0 \%$; sand $48.7 \%$; silt $25.3 \%$; cation exchange capacity pH $7.013 .84 \mathrm{cmo}_{\mathrm{c}} \mathrm{dm}^{-3}$; $\mathrm{pH}\left(\mathrm{H}_{2} \mathrm{O}\right) 5.4$; organic matter $2.8 \%$; P $15 \mathrm{mg} \mathrm{dm}^{-3}$; K $160 \mathrm{mg} \mathrm{dm}^{-3}$; Ca $7.8 \mathrm{mg} \mathrm{dm}^{-3}$; $\mathrm{Mn}<50 \mathrm{mg} \mathrm{dm}^{-3}$; Cu $4.7 \mathrm{mg} \mathrm{dm}^{-3} ; \mathrm{Zn} 22.1 \mathrm{mg} \mathrm{dm}^{-3} ; \mathrm{Fe}>5 \mathrm{~g} \mathrm{dm}^{-3} ; \mathrm{Al} 0.5 \mathrm{cmo}_{\mathrm{c}} \mathrm{dm}^{-3} ; \mathrm{Mg} 1.3$ $\mathrm{cmo}_{\mathrm{c}} \mathrm{dm}^{-3}$.

\section{Test substances and concentrations}

The treatments consisted of increasing concentrations of the commercial formulations of the fungicide Comet ${ }^{\circledR}$ (BASF), containing: Methyl N- \{2- [1- (4-chlorophenyl) -1H-pyrazol-3-yloxymethyl] phenyl\} (N-methoxy) carbamate (pyraclostrobin) $250 \mathrm{~g} \mathrm{~L}^{-1}(25 \%$ $\mathrm{m} / \mathrm{v}$ ), and the fungicide + insecticide Standak ${ }^{\circledR}$ Top (BASF), containing: Methyl N- \{2- [1- (4-chlorophenyl) -1H-pyrazol-3-yloxymethyl] phenyl $\}$-methoxy) Carbamate (pyraclostrobin) $25 \mathrm{~g} \mathrm{~L}^{-1}(2.5 \% \mathrm{w} / \mathrm{v})$; Dimethyl 4,4 '- (o-phenylene) bis (3-thioallophanate) (thiophanate-methyl) $225 \mathrm{~g} \mathrm{~L}^{-1}(22.5 \% \mathrm{w} / \mathrm{v})$ and (RS) -5-amino-1- (2,6- dichloro- $\alpha, \quad \alpha, \quad \alpha$-trifluoro-p-tolyl) -4-trifluoromethylsulfinylpyrazole-3-carbonitrile (fipronil) $250 \mathrm{~g} \mathrm{~L}^{-1}(25 \% \mathrm{w} / \mathrm{v})$ applied to Inceptisol. The pesticides were diluted and homogenized in deionized water before the start of the test, and applied to the soil during the correction of moisture.

The final concentrations were calculated from the results obtained by the acute pre-tests and were determined by the commercially recommended doses of the products (predicted environmental concentrations - PEC), adjusted to values above and below these. The PEC of the application of the product in its commercial recommendation was extrapolated from the values obtained by multiplying the recommended volume per hectare (ha), assuming soil density of $1 \mathrm{~g} \mathrm{~cm}^{-3}$ and $0.10 \mathrm{~m}$ depth layer (label directions of pesticide Comet $^{\oplus}$ ); and the recommended volume per kilogram of seed used per hectare (ha) (label directions of pesticide Standak ${ }^{\circledR}$ Top). For both products, soybean (Glycine max) was used as reference crop and the number of seeds per hectare was calculated using $0.50 \mathrm{~m}$ spacing and 12 seeds per linear meter $\left(50 \mathrm{~kg}\right.$ of seeds ha $\left.{ }^{-1}\right)$. These procedures followed the methodology described by Alves et al. (2013).

The tested concentrations of fungicide were $0.35,0.70,1.40,2.10$, 2.80 and $4.00 \mathrm{mg} \mathrm{kg}^{-1}$ soil, and for the fungicide + insecticide were 0.20 , $0.60,1.20,1.80,2.40$ and $3.00 \mathrm{mg} \mathrm{kg}^{-1}$. The control treatment did not receive the products and only had its moisture corrected using deion- ized water. The environmentally predicted concentrations of the active ingredients present in pesticide formulations are described in Table 1.

\section{Acute and chronic toxicity tests}

The toxicity effects of the tested products on springtails were evaluated following the methods described by the protocol ISO 11267 (ISO, 1999), by means of lethality and reproduction tests. The experiment was conducted in a completely randomized design with six replicates. Each experimental unit consisted of plastic pots, which received $30 \mathrm{~g}$ of the natural soil contaminated with the different concentrations of the pesticides tested. During the test period, soil moisture was corrected weekly, and the organisms were fed at 14-day interval with $2 \mathrm{mg}$ of dry granulated yeast (S. cerevisiae).

At 28 days, the contents of the plastic pots were transferred to a larger container containing water and a few drops of black paint. The contents were mixed so that the organisms could rise to the surface. Each experimental unit was photographed for subsequent counting regarding adult survival and number of juveniles generated (differentiated by body size) using ImageJ 1.5 software (SCHNEIDER; RASBAND; ELICEIRI, 2012).

\section{Data analysis}

Survival and reproduction results were tested for normality and homogeneity by the Kolmogorov-Smirnov and Levene tests, respectively. The data were submitted to analysis of variance (One-way ANOVA), and the means were statistically compared by the Dunnett test $(\mathrm{p}<0.05)$. Data that did not meet the assumptions were submitted to the Kruskal-Wallis test, followed by the Bonferroni post-test, using Statistica Software 7 (STATSOFT, 2004). $\mathrm{EC}_{20}$ values (estimated concentration to cause one or more specific effects capable of affecting $20 \%$ of the organisms) were estimated by regressions through the Hormesis model using Software Statistica 7.0 (STATSOFT, 2004). The values of non-observed effect concentration (NOEC) and lowest observed effect concentration (LOEC) were also determined. $\mathrm{LC}_{50}$ values (lethal concentration) were determined by PriProbit ${ }^{\circledR}$ Software 1.63 (SAKUMA, 1998).

\section{Results}

\section{Test validation}

Acute and chronic toxicity tests met the validation criteria according to ISO 11267 (ISO, 1999). Adult survival in the control treatment

Table 1 - Description of commercial formulations of tested pesticides and their active ingredients (a.i.) at predicted environmental concentrations (PEC) at commercial doses for soybean cultivation.

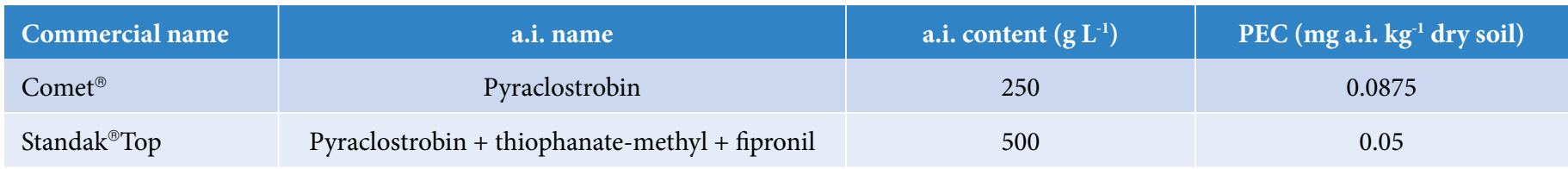


was $83.3 \%$. In the reproduction tests, the number of juveniles in the control treatment was higher than 100 individuals per replicate (mean of 278 juveniles), with coefficients of variation of 15.9 and $23.1 \%$ for the lethality and reproduction tests, respectively.

\section{Effects on the survival of Folsomia candida}

Both commercial formulations of pesticides were lethal to F. candida, causing a reduction in the survival of the individuals $(\mathrm{p}<0.05)$. The significant lethality of springtails was found from the first tested concentration of fungicide (a.i. pyraclostrobin) (0.35 mg kg-1 soil) (Figure $1 \mathrm{~A}$ ), but the $\mathrm{LC}_{50}$ values could not be calculated. For the formulation of the fungicide + insecticide (a.i. pyraclostrobin + thiophanate-methyl + fipronil), significant mortality was found when the organisms were exposed to concentrations equal or higher than $2.40 \mathrm{mg} \mathrm{kg}^{-1}$ soil $\left(\mathrm{LC}_{50}>3.00 \mathrm{mg} \mathrm{kg}^{-1}\right)$ (Figure 1B).

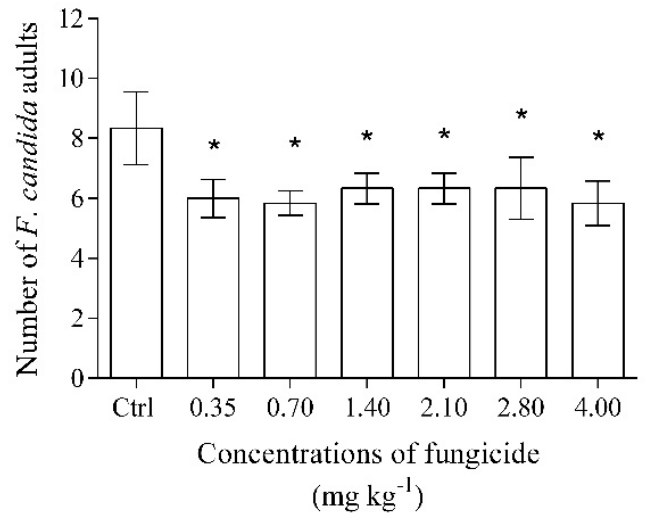

\section{Effects on the reproduction of Folsomia candida}

Although both formulations had an effect on survival, reproduction was little affected by the concentrations of the commercial formulations of the tested pesticides. The effects of reduction in the reproductive rates of the species were observed only at the highest concentrations of the fungicide. The formulation of the fungicide containing pyraclostrobin was able to significantly affect the reproduction rate of the organisms $(\mathrm{p}<0.05)$, causing a reduction at the concentration of $4.00 \mathrm{mg} \mathrm{kg}^{-1}$, with $\mathrm{EC}_{20}$ values of $3.38 \mathrm{mg} \mathrm{kg}^{-1}$ soil (2.79-3.96) (Figure 2A). The NOEC and LOEC values were 2.80 and 4.00 $\mathrm{mg} \mathrm{kg}{ }^{-1}$, respectively. The values of $\mathrm{EC}_{20}$ for fungicide + insecticide could not be calculated because the product was not able to cause significant reduction in reproduction at the concentrations tested (Figure 2B).

\section{Discussion}

Both formulations caused a lethal effect on the organisms, especially the fungicide containing the active ingredient pyraclostrobin, which

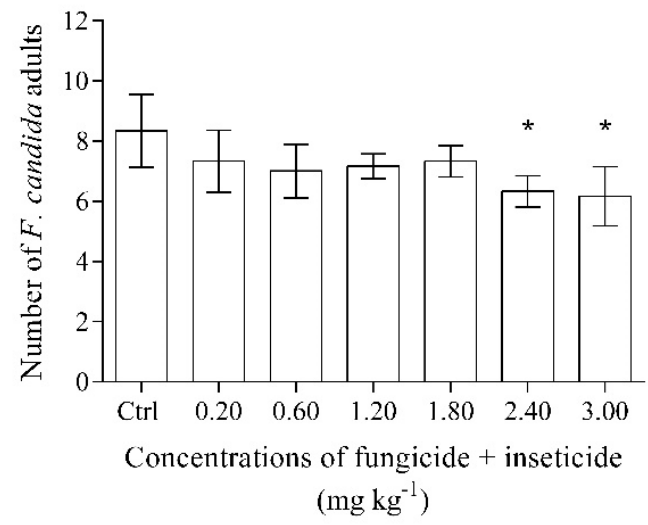

Figure 1 - Mean number of live adults of Folsomia candida in Inceptisol treated with concentrations of (A) fungicide and (B) fungicide + insecticide.

${ }^{*}$ A significant reduction in the number of adults compared to control $(\mathrm{p}<0.05)$, by the $(A)$ Dunnett test and the $(B)$ Bonferroni test; $T$ : standard deviation $(n=6)$.
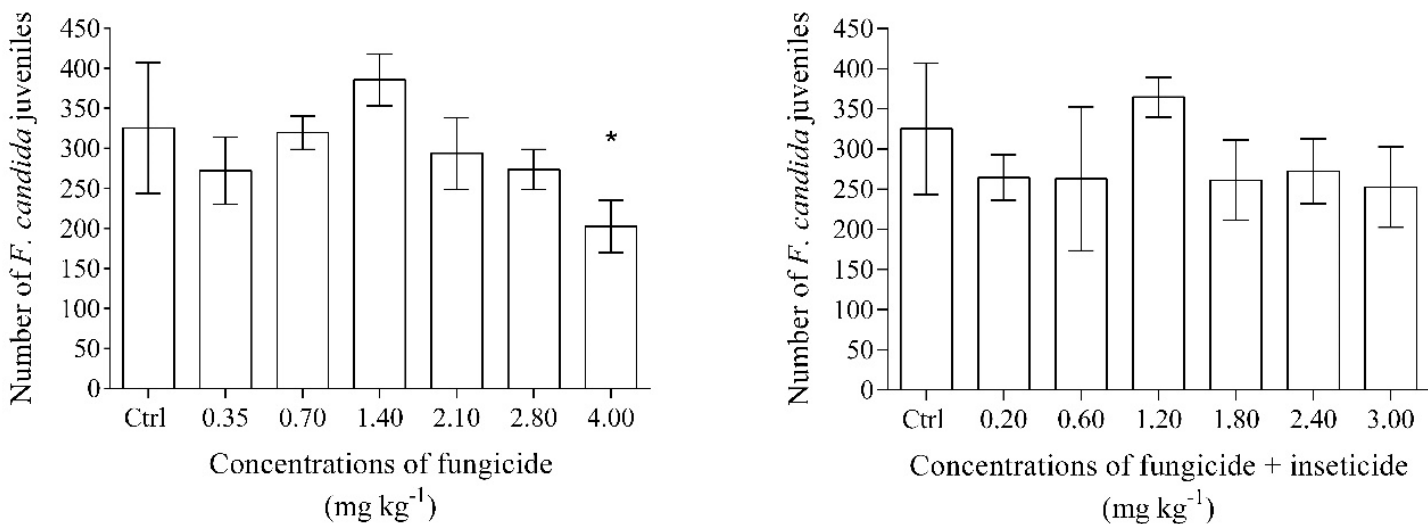

Figure 2 - Mean of Folsomia candida juveniles in Inceptisol treated with concentrations of (A) fungicide and (B) fungicide + insecticide. ${ }^{*}$ A significant reduction in the number of juveniles compared to control $(\mathrm{p}<0.05)$, by the Dunnett test; $\mathrm{T}$ : standard deviation $(\mathrm{n}=6)$. 
even at the lowest concentration caused the lethality of the organisms, demonstrating greater toxicity than the formulation of the fungicide + insecticide, containing pyraclostrobin, thiophanate-methyl and fipronil, which caused lethality at higher concentrations. The results obtained in our study differ from those of other studies that observed that springtails were less sensitive to fungicides than to insecticides (DAAM et al., 2011; ALVES et al., 2014). However, there are studies that also indicate lower rates of reproduction of springtails when exposed to fungicides (JÄNSCH et al., 2006; GÜNDEL et al., 2019).

Only the fungicide caused a reduction in the reproduction of springtails, an effect observed only at the highest concentration (4.00 $\mathrm{mg} \mathrm{kg}^{-1}$ soil). The lower sensitivity to the formulation of the fungicide + insecticide may be related to the lower concentration of the active ingredient pyraclostrobin in its formulation (2.5\%), which corresponds to $0.005 \mathrm{mg} \mathrm{kg}^{-1}$ soil at the lowest concentration tested when compared to the commercial formulation in which pyraclostrobin has no effect combined with other substances, and has a concentration of $25 \%$ of active ingredient ( $0.0875 \mathrm{mg} \mathrm{kg}^{-1}$ soil at the lowest concentration tested).

No other studies have been found demonstrating the effect of the active ingredients thiophanate-methyl and pyraclostrobin on springtails. The more severe effect of pyraclostrobin on survival than on the reproduction of organisms in laboratory tests may be related to the reduction in food sources, considering these organisms mainly feed on fungi (SEGAT et al., 2018). These organisms are mostly mycophagous, consuming any kind of fungi, lichens, bacteria and organic material available in the environment (SEGAT et al., 2018). Under environmental conditions, the application of fungicides affects many organisms, including bacteria, fungi, yeasts and arbuscular mycorrhizal fungi, which can serve as a source of food for springtails (JANSA; WIEMKEN; FROSSARD, 2006; BENDING; RODRÍGUEZ-CRUZ; LINCOLN, 2007; CAMPOS et al., 2015).

Therefore, the decrease in food availability can lead to the lethality of these individuals. At first, the application of these pesticides may not affect the ability of these organisms to reproduce, allowing the survivors to continue reproducing normally. However, the intensification of this effect (mortality by the use of pesticides) can determine in the medium and long term whether or not survivors will be able to reproduce, depending on the applied concentrations of the pesticides, even if the surviving springtails still remain able to reproduce (VAN GESTEL et al., 2017).

No $\mathrm{LC}_{50}$ and $\mathrm{EC}_{50}$ values were found for the $F$. candida species obtained from the validation and registration of pyraclostrobin and thiophanate-methyl. For earthworms of the Eisenia fetida species, pyraclostrobin was able to cause oxidative damage at concentrations of $0.1 \mathrm{mg} \mathrm{kg}^{-1}$ soil, and damage to DNA at concentrations of 1.0 and $2.5 \mathrm{mg} \mathrm{kg}^{-1}$ soil (MA et al., 2019). In the present study, the LOEC on the reproduction of springtails was $0.60 \mathrm{mg} \mathrm{kg}^{-1}$ soil and the $\mathrm{EC}_{20}$ value calculated was $3.38 \mathrm{mg} \mathrm{kg}^{-1}$ soil (2.79-3.96), which were below the con- centrations that caused effects on worms in other studies performed with pyraclostrobin as the only active ingredient.

Regarding the effect of the other active ingredient present in the tested products, fipronil caused toxicity to F. candida species, affecting its survival and reproduction, with estimated LOEC value of $1.0 \mathrm{mg} \mathrm{kg}^{-1}$ soil and $\mathrm{EC}_{50}$ of $0.18-0.35 \mathrm{mg} \mathrm{kg}^{-1}$ in natural soil, Oxisol (ZORTÉA et al., 2018b). In the present study, even at the highest concentration tested $\left(3.00 \mathrm{mg} \mathrm{kg}^{-1}\right.$ soil), which corresponds to $0.75 \mathrm{mg} \mathrm{kg}^{-1}$ soil of the active ingredient fipronil, no effects were observed on the reproductive rates of the organisms. Although it is within the range estimated by Zortéa et al. (2018b), capable of causing effects on the reproductive rates of $F$. candida, such work is related to the active ingredient fipronil in veterinary drug formulations and does not present the interaction of active ingredients as in the present study. The mixtures of pesticides may exhibit synergistic or antagonistic action, which still needs to be better explored (YANG et al., 2017). The same authors, studying combinations of insecticides and herbicides, observed that such effects depend on the proportion of the active ingredients in the mixtures, taking as an example the insecticides chlorpyrifos and clothianidin, which had either a synergistic effect or an antagonistic effect.

The effect of the interaction between the active ingredients pyraclostrobin, thiophanate-methyl and fipronil, present in the formulation of the fungicide + insecticide, is not known. These results may also vary depending on the type of soil tested, considering that the toxicity of the molecules can vary in the natural soils, being related to the physicochemical characteristics and the organic matter content present in the soil (NATAL-DA-LUZ; RÖMBKE; SOUSA, 2008).

Under natural conditions, the reduction in the abundance of springtails can affect the rates of decomposition of organic matter and consequently the cycling of nutrients performed by these organisms. As demonstrated by Brooks et al. (2005), exposure to insecticides promoted an $80 \%$ reduction in springtails in agricultural areas. This reduction caused by exposure to pesticides resulted in a $45 \%$ reduction in soil organic matter degradation, demonstrating that, although the effects are acute and do not affect the perpetuation of the species in the surrounding environment, the reduction in the number of such organisms in their natural environments can affect important processes that occur in the terrestrial ecosystem. The decomposition of organic matter and nutrient cycling performed by springtails (BUCH et al., 2016) may be impacted by the use of such substances that cause both acute and chronic effects on such organisms.

The effect of pesticides may still be noticeable over generations due to the persistence of substances in the soil. Mortality and reduction in the reproductive rates of $F$. candida were observed after exposure to insecticides such as imidacloprid and thiacloprid even over several generations, due to the persistence characteristics of the molecules in the soil (VAN GESTEL et al., 2017). Pyraclostrobin, thiophanate-methyl and fipronil have half-life values $\left(\mathrm{DT}_{50}\right)$ of $12-101$ 
days, 0.48-0.74 days and 120-308 days, respectively (EC, 2004; 2005; 2011), and may have a cumulative effect on the soil, especially if we consider that the products are often reapplied in the same crop, so these substances are able to reach high concentrations. Pesticides are used intensively and inadequately in many agricultural areas, contributing to high concentrations in the soil.

Studies on natural soils are particularly important because the effects of toxicity can vary when compared to the artificial soils standardized by Organisation for Economic Co-operation and Development (OECD), where the sorption capacity of the organic matter present in them can influence the toxicity of pesticides, especially when applied to the field. As an example, the insecticide dimethoate showed higher $\mathrm{EC}_{50}$ values for springtails in OECD artificial soil with $10 \%$ of total organic matter and $8.6 \%$ of humified organic matter than in the same soil with only $5 \%$ of total organic matter and $1.8 \%$ of humid organic matter (MARTIKAINEN; KROGH, 1999). The subtropical soil, classified as Inceptisol, has buffering agents such as clay and significant organic matter contents in its composition and, when the pesticides are applied, they can remain adsorbed on the organic material and thus remain available to the soil organisms for many years after the application to the field, varying according to the persistence of the molecules of the active ingredients present in the commercial formulations of pesticides, prolonging the period of exposure of these organisms to these substances (SÁNCHEZ-BAYO, 2011).

Studies on natural soils are particularly important in the field of terrestrial ecotoxicology. Authors report that the physicochemical characteristics, as well as the organic matter content and high clay content present in natural soils are directly related to the toxicity of the molecules (NATAL-DA-LUZ; RÖMBKE; SOUSA, 2008; ZORTÉA et al., 2018a). The active ingredient molecules present in pesticide formulations may remain adsorbed on organic matter, with a tendency of pesticides to cause a lower toxicity effect on natural soils, when com- pared to artificial soil tests (MARTIKAINEN; KROGH, 1999). Even in natural soil, both products demonstrated toxic potential for the $F$. candida species, corroborating the need for the use of natural soils in pesticide toxicity tests.

\section{Conclusion}

The organisms of the species $F$. candida were sensitive to both tested substances. The variation in the concentrations of fungicide (a.i. pyraclostrobin) and of the commercial formulation of the fungicide + insecticide (a.i. pyraclostrobin + thiophanate-methyl + fipronil) cause higher acute toxicity effect when compared to the chronic effect on springtails in natural soil. The reproduction of $F$. candida was affected only when exposed to higher concentrations of the fungicide, with no effect of the product containing fungicide + insecticide. The results showed that exposure to such products may represent a threat to the functionality of the services performed by these soil organisms in subtropical natural soils. However, we recommend that other non-target organisms (such as plants, invertebrates, and microorganisms) must be evaluated, because they may be more sensitive to these products than springtails.

\section{Acknowledgments}

The authors are grateful to the Coordenação de Aperfeiçoamento de Pessoal de Nivel Superior (Coordination for the Improvement of Higher Education Personnel - CAPES) for the scholarship granted to the first author and to the Universidade Comunitária da Região de Chapecó (Unochapecó) for funding the research and granting the scientific initiation scholarship. D. B. thanks Conselho Nacional de Desenvolvimento Científico e Tecnológico (National Council for Scientific and Technological Development - CNPq) for the Research Productivity Grant (process number 305939/2018-1). L. C. I. O. F. thanks CNPq for the Scholarship granted (process number 155778/2018-8).

\section{Contribution of authors:}

Giordani, I.A.: Formal analysis, Conceptualization, Data curation, Writing - First draft, Funding acquisition; Project administration. Busatta, E.: Formal analysis, Conceptualization, Data curation, Writing - First draft. Bonfim, E.: Formal analysis, Conceptualization, Data curation, Writing - First draft. Oliveira Filho, L.C.I.: Formal analysis, Conceptualization, Data curation, Writing - First draft. Baretta, D.: Formal analysis, Conceptualization, Data curation, Writing First draft. Baretta, C.R.D.M.: Formal analysis, Conceptualization, Data curation, Writing - First draft, Funding acquisition; Project administration.

\section{References}

ALVES, P. R. L.; CARDOSO, E. J. B. N.; MARTINES, A. M.; SOUSA, J. P.; PASINI, A. Earthworm ecotoxicological assessments of pesticides used to treat seeds under tropical conditions. Chemosphere, v. 90, n. 11, p. 2674-2682, 2013. https://doi.org/10.1016/j.chemosphere.2012.11.046

ALVES, P. R. L.; CARDOSO, E. J. B. N.; MARTINES, A. M.; SOUSA, J. P.; PASINI, A. Seed dressing pesticides on springtails in two ecotoxicological laboratory tests. Ecotoxicology and Environmental Safety, v. 105, p. 65-71, 2014 https://doi.org/10.1016/j.ecoenv.2014.04.010
BENDING, G. D.; RODRÍGUEZ-CRUZ, M. S.; LINCOLN, S. D. Fungicide impacts on microbial communities in soils with contrasting management histories. Chemosphere, v. 69, n. 1, p. 82-88, 2007. https://doi.org/10.1016/j. chemosphere.2007.04.042

BERTRAND, M.; BAROT, S.; BLOUIN, M.; WHALEN, J.; OLIVEIRA, T.; ROGER-ESTRADE, J. Earthworm services for cropping systems. A review. Agronomy for Sustainable Development, v. 35, p. 553-567, 2015. https://doi. org/10.1007/s13593-014-0269-7 
BRASIL. Ministério da Agricultura, Pecuária e Abastecimento (MAPA). AGROFIT. Sistemas de agrotóxicos fitossanitários. Brasil: MAPA, 2020. Available in: <http://agrofit.agricultura.gov.br/agrofit_cons/principal_agrofit_ cons $>$. Accessed on: Abr. 18, 2020.

BROOKS, D. R.; CLARK, S. J.; PERRY, J. N.; BOHAN, D. A.; CHAMPION, G. T.; FIRBANK, L. G.; HAUGHTON, A. J.; HAWES, C.; HEARD, M. S.; WOIWOD, I. P. Invertebrate biodiversity in maize following withdrawal of triazine herbicides. Proceedings of the Royal Society B: Biological Sciences, v. 272, n. 1571, p. 1497-1502, 2005. https://doi.org/10.1098/rspb.2005.3102

BUCH, A. C.; NIEMEYER, J. C.; FERNANDES CORREIA, M. E.; SILVAFILHO, E. V. Ecotoxicity of mercury to Folsomia candida and Proisotoma minuta (Collembola: Isotomidae) in tropical soils: Baseline for ecological risk assessment. Ecotoxicology and Environmental Safety, v. 127, p. 22-29, 2016. https://doi.org/10.1016/j.ecoenv.2016.01.009

CAMPOS, A. A. B.; SCOTTON, J. C.; COSTA, W. L. F.; GIASSI, V.; PINTO, D. F. P.; HOMMA, S. K. Seleção de fungicidas visando à preservação de fungos micorrízicos arbusculares nativos no cultivo do feijoeiro. Revista Brasileira de Engenharia Agrícola e Ambiental, v. 19, n. 9, p. 898-902, 2015. https://doi. org/10.1590/1807-1929/agriambi.v19n9p898-902

CARNEIRO, F.; RIGOTTO, R. M.; AUGUSTO, L. G.; FRIEDRICH, K. K.; BÚRIGO, A. C. Dossiê ABRASCO: um alerta sobre os impactos dos agrotóxicos na saúde. Rio de Janeiro: EPSJV; São Paulo: Expressão Popular, 2015.

DAAM, M. A.; LEITÃO, S.; CEREJEIRA, M. J.; SOUSA, J. P. Comparing the sensitivity of soil invertebrates to pesticides with that of Eisenia fetida. Chemosphere, v. 85, n. 6, p. 1040-1047, 2011. https://doi.org/10.1016/j. chemosphere.2011.07.032

DABROWSKI, J. M.; SHADUNG, J. M.; WEPENER, V. Prioritizing agricultural pesticides used in South Africa based on their environmental mobility and potential human health effects. Environment International, v. 62, p. 31-40, 2014. https://doi.org/10.1016/j.envint.2013.10.001

EMPRESA BRASILEIRA DE PESQUISA AGROPECUÁRIA (EMBRAPA). Manual de métodos de análise de solo. 2. ed. Rio de Janeiro: EMBRAPA Solos, 2011.

EUROPEAN COMMISSION (EC). Review report for the active substance pyraclostrobin. Finalised in the Standing Committee on the Food Chain and Animal Health at its meeting on 28 November 2003 in view of the inclusion of pyraclostrobin in Annex I of Council Directive 91/414/EEC. SANCO/1420/2001Final, 08 September 2004. Brussels: European Commission, 2004. Available at: $<$ http://ec.europa.eu/food/plant/pesticides/eu-pesticides-database/ public/?event=activesubstance.ViewReview\&id=379>. Accessed on: Dec. 4, 2019.

EUROPEAN COMMISSION (EC). Review report for the active substance thiophanate-methyl. inalised in the Standing Committee on the Food Chain and Animal Health at its meeting on 15 February 2005 in view of the inclusion of thiophanate-methyl in Annex I of Directive 91/414/EEC. 5030/VI, 2005. Brussels: European Commission, 2005. Available at: $<$ http://ec.europa.eu/ food/plant/pesticides/eu-pesticides-database/public/?event=activesubstance. ViewReview\&id=187>. Accessed on: Dec. 4, 2019.

EUROPEAN COMMISSION (EC). Fipronil, product-type PT18 (insecticides, acaricides and products to control other arthropods). Finalised in the Standing Committee on Biocidal Products at its meeting on 6th May 2011 in view of its inclusion in Annex I to Directive 98/8/EC, 2011. Brussels: European Commission, 2011. Available at: http://dissemination.echa.europa.eu/ Biocides/ActiveSubstances/0033-18/0033-18_Assessment_Report.pdf. Accessed on: Dec. 4, 2019.

EUROPEAN COMMISSION (EC). The combination effects of chemicals, Chemical mixtures. Communication from the Commission to the Council, COM(2012) 252 final. Brussels: European Commission, 2012. Available at: <http://eur-lex.europa.eu/legal-content/EN/TXT/ PDF/?uri=CELEX:52012DC0252\&from=EN>. Accessed on: Dec. 4, 2019.

GÜNDEL, S. S.; REIS, T. R.; COPETTI, P. M.; FAVARIN, F. R.; SAGRILLO, M. R.; SILVA, A. S.; SEGAT, J. C.; BARETTA, D.; OURIQUE, A. F. Evaluation of cytotoxicity, genotoxicity and ecotoxicity of nanoemulsions containing Mancozeb and Eugenol. Ecotoxicology and Environmental Safety, v. 169, p. 207 215, 2019. https://doi.org/10.1016/j.ecoenv.2018.11.023

INSTITUTO BRASILEIRO DO MEIO AMBIENTE E DOS RECURSOS NATURAIS RENOVÁVEIS (IBAMA). Boletins anuais de produção, importação, exportação e vendas de agrotóxicos no Brasil. Brasil: IBAMA, 2019. Available in: $<$ https://www.ibama.gov.br/agrotoxicos/relatorios-decomercializacao-de-agrotoxicos $>$. Accessed on: Abr. 18, 2020.

INTERNATIONAL ORGANIZATION FOR STANDARDIZATION (ISO). Soil quality - Inhibition of reproduction of Collembola (Folsomia candida) by soil pollutants. ISO 11267. Geneva: ISO, 1999.

JANSA, J.; WIEMKEN, A.; FROSSARD, E. The effects of agricultural practices on arbuscular mycorrhizal fungi. Geological Society, London, Special Publications, v. 266, p. 89-115, 2006. https://doi.org/10.1144/GSL. SP.2006.266.01.08

JÄNSCH, S.; FRAMPTON, G. K.; RÖMBKE, J.; VAN DEN BRINK, P. J.; SCOTT-FORDSMAND, J. J. Effects of pesticides on soil invertebrates in model ecosystem and field studies: a review and comparison with laboratory toxicity data. Environmental Toxicology and Chemistry, v. 25, n. 9, p. 2490-2501, 2006. https://doi.org/10.1897/05-439R.1

JEGEDE, O. O.; OWOJORI, O. J.; RÖMBKE, J. Temperature influences the toxicity of deltamethrin, chlorpyrifos and dimethoate to the predatory mite Hypoaspis aculeifer (Acari) and the springtail Folsomia candida (Collembola). Ecotoxicology and Environmental Safety, v. 140, p. 214-221, 2017. https://doi. org/10.1016/j.ecoenv.2017.02.046

KOUTSAFTIS, A.; AOYAMA, I. Toxicity of four antifouling biocides and their mixtures on the brine shrimp Artemia salina. Science of The Total Environment, v. 387 , n. 1-3, p. 166-174, 2007. https://doi.org/10.1016/j.scitotenv.2007.07.023

LORENZATTO, L.; SILVA, M. I.; ROMAN JUNIOR, W.; RODRIGUES JUNIOR, S.; SÁ, C.; CORRALO, V. Rural workers exposure to organophosphates and carbamates. Revista Brasileira de Ciências Ambientais, v. 55, n. 1, p. 19-31, 2020. https://doi.org/10.5327/Z2176-947820200528

MA, J.; CHENG, C.; DU, Z.; LI, B.; WANG, J.; WANG, J.; WANG, Z.; ZHU, L. Toxicological effects of pyraclostrobin on the antioxidant defense system and DNA damage in earthworms (Eisenia fetida). Ecological Indicators, v. 101, p. 111-116, 2019. https://doi.org/10.1016/j.ecolind.2019.01.015

MAJOLO, F.; REMPEL, C. Impact of the use of pesticides by rural workers in Brazil. Revista Brasileira de Ambientais, n. 50, p. 1-25, 2018. https://doi. org/10.5327/Z2176-947820180357

MARTIKAINEN, E. A. T.; KROGH, P. H. Effects of soil organic matter content and temperature on toxicity of dimethoate to Folsomia fimetaria (Collembola: Isotomiidae). Environmental Toxicology and Chemistry, v. 18, n. 5, p. 865-872, 1999. https://doi.org/10.1002/etc.5620180508

NASCIMENTO, L. C.; NAVAL, L. P. Toxicidade determinada pelo uso dos agrotóxicos em organismos indicadores de qualidade da água. Revista Brasileira de Ciências Ambientais, n. 53, p. 69-80, 2019. https://doi.org/10.5327/ Z2176-947820190466

NATAL-DA-LUZ, T.; RÖMBKE, J.; SOUSA, J. P. Avoidance tests in site-specific risk assessment--influence of soil properties on the avoidance response of Collembola and earthworms. Environmental Toxicology and Chemistry, v. 27, n. 5, p. 1112-1117, 2008. https://doi.org/10.1897/07-386.1 
PELAEZ, V. M.; SILVA, L.; GUIMARÃES, T.; RI, F.; TEODOROVICZ, T. A

(des)coordenação de políticas para a indústria de agrotóxicos no Brasil. Revista Brasileira de Inovação, v. 14, p. 153-178, 2015. https://doi.org/10.20396/rbi. v14i0.8649104

PIMENTEL, D. Amounts of pesticides reaching target pests: Environmental impacts and ethics. Journal of Agriculture and Environmental Ethics, v. 8, p. 1729, 1995. https://doi.org/10.1007/BF02286399

SAKUMA, M. Probit analysis of preference data. Applied Entomology and Zoology, v. 33, n. 3, p. 339-347, 1998. https://doi.org/10.1303/aez.33.339

SÁNCHEZ-BAYO, F. Impacts of agricultural pesticides on terrestrial ecosystems. In: SÁNCHEZ-BAYO, F.; VAN DEN BRINK, P.; MANN, R. (orgs.). Ecological Impacts of Toxic Chemicals. [s.1.]: Bentham Science Publishers, 2011. p. 63-87.

SCHNEIDER, C. A.; RASBAND, W. S.; ELICEIRI, K. W. NIH Image to ImageJ: 25 years of image analysis. Nature Methods, v. 9, p. 671-675, 2012. https://doi. org/10.1038/nmeth.2089

SEGAT, J. C.; MACCARI, A. P.; OLIVEIRA FILHO, L. C. I.; ZEPPELINI, D.; LOPES-LEITZKE, E. R. Ecotoxicologia Terrestre. In: OLIVEIRA FILHO, L. C. I.; SEGAT, J. C.; BARETTA, D.; KLAUBERG FILHO, O. (orgs.). Ecotoxicologia Terrestre: Métodos e aplicações de ensaios com Collembola e Isopoda. Florianópolis: Udesc, 2018. p. 11-50.

SIMÕES, T.; NOVAIS, S. C.; NATAL-DA-LUZ, T.; DEVREESE, B.; DE BOER, T.; ROELOFS, D.; SOUSA, J. P.; VAN STRAALEN, N. M.; LEMOS, M. F. L. Using time-lapse omics correlations to integrate toxicological pathways of a formulated fungicide in a soil invertebrate. Environmental Pollution, v. 246, p. 845-854, 2019. https://doi.org/10.1016/j.envpol.2018.12.069

STATSOFT. STATISTICA (data analysis software system). Tulsa, 2004. Available at: <www.statsoft.com>. Accessed on Dec. 4, 2015.
TEDESCO, M. J.; GIANELLO, C.; BISSANI, C. A.; VOLKWEISS, S. J. Análises de Solo, Plantas e Outros Materiais. Porto Alegre: Universidade Federal do Rio Grande do Sul, 1995.

VAN GESTEL, C. A. M.; LIMA E SILVA, C.; LAM, T.; KOEKKOEK, J. C.; LAMOREE, M. H.; VERWEIJ, R. A. Multigeneration toxicity of imidacloprid and thiacloprid to Folsomia candida. Ecotoxicology, v. 26, p. 320-328, 2017. https://doi.org/10.1007/s10646-017-1765-8

YANG, G.; CHEN, C.; WANG, Y.; PENG, Q.; ZHAO, H.; GUO, D.; WANG Q.; QIAN, Y. Mixture toxicity of four commonly used pesticides at different effect levels to the epigeic earthworm, Eisenia fetida. Ecotoxicology and Environmental Safety, v. 142, p. 29-39, 2017. https://doi.org/10.1016/j. ecoenv.2017.03.037

YOUNG, S. L.; GOLDOWSKY-DILL, N. W.; MUHAMMAD, J.; EPSTEIN, M. M. Connecting experts in the agricultural and meteorological sciences to advance knowledge of pest management in a changing climate. Science of The Total Environment, v. 673, p. 694-698, 2019. https://doi.org/10.1016/j. scitotenv.2019.04.126

ZHANG, C.; ZHOU, T.; ZHU, L.; JUHASZ, A.; DU, Z.; LI, B.; WANG, J.; WANG, J.; SUN, Y. Response of soil microbes after direct contact with pyraclostrobin in fluvo-aquic soil. Environmental Pollution, v. 255, part I, p. 113-164, 2019. https://doi.org/10.1016/j.envpol.2019.113164

ZORTÉA, T.; REIS, T. R.; SERAFINI, S.; SOUSA, J. P.; SILVA, A. S.; BARETTA, D. Ecotoxicological effect of fipronil and its metabolites on Folsomia candida in tropical soils. Environmental Toxicology and Pharmacology, v. 62, p. 203-209, 2018a. https://doi.org/10.1016/j.etap.2018.07.011

ZORTÉA, T.; SILVA, A. S.; REIS, T. R.; SEGAT, J. C.; PAULINO, A. T.; SOUSA, J. P.; BARETTA, D. Ecotoxicological effects of fipronil, neem cake and neem extract in edaphic organisms from tropical soil. Ecotoxicology and Environmental Safety, v. 166, p. 207-214, 2018b. https://doi.org/10.1016/j.ecoenv.2018.09.061 